\title{
Makna Ayat-ayat Perumpamaan Di Dalam Surat Ali Imran
}

\author{
Ferki Ahmad Marlion \\ Institut Agama Islam Negeri Batusangkar \\ Email: ferkialfateh92@gmail.com \\ Tri Yuliana Wijayanti \\ Institut Agama Islam Negeri Batusangkar \\ Email: tri.yw@iainbatusangkar.ac.id
}

\begin{abstract}
The Qur'an is the perfect holy book that was sent down through the Prophet Muhammad. This book is filled with miracles and one of the miracles of the Qur'an lies in the arrangement of parable verses which are a framework that displays sentences in the form of a beautiful parable, so that it sticks firmly in the soul and makes it easier for humans to understand, accept, so that it is easy to apply the meaning of the verse in daily life. One of the letters contained in the verses of the parable is the Surah Ali Imran. By using the literature method from various reference sources, the researcher tried to examine the meaning of the parable verses in Surat Ali Imran. Based on the results of the deductive analysis conducted by the researcher, it can be described that there are three parable verses in Surah Ali Imran, namely verses 59, 117, and 103. Of the three verses, two verses are expressed in clear parables (verse 59 and verse 117) and one more verses are revealed with hidden parables (verse 103). These three verses reveal the fact about the creation of Prophet Adam (created without a father and mother) which is actually more amazing than the creation of Prophet Isa (created without a mother). Through these three verses, a lesson can be learned about the importance of clinging to the rope of Allah and the uselessness of the assets that are given away to fight against Allah and His Messenger.
\end{abstract}

Keyword: Al-Qur'an, Parable Verses, Surah Ali Imran

Abstrak: Al-Qur'an merupakan kitab suci yang sempurna yang diturunkan melalui Nabi Muhammad saw. Kitab ini dipenuhi dengan kemu'jizatan dan salah satu kemukjizatan Al-Qur'an terletak pada susunan ayat-ayat perumpamaan yang merupakan salah satu kerangka yang menampilkan kalimat dalam bentuk perumpamaan yang indah, sehingga menancap kuat pada jiwa dan memudahkan manusia dalam memahami, menerima, sehingga mudah dalam mengaplikasikan maksud ayat dalam hidup keseharian. Salah satu surat yang terkandung didalamnya ayat-ayat perumpamaan ialah surat Ali Imran. Dengan menggunakan metode telah pustaka dari berbagai sumber referensi peneliti mencoba untuk meneliti makna ayat-ayat perumpamaan di dalam Surat Ali Imran. Berdasarkan hasil analisis deduktif yang dilakukan peneliti, dapat dideskripsikan bahwa terdapat tiga ayat perumpamaan dalam surat Ali Imran, yakni ayat 59, 117, dan 103. Dari ketiga ayat tersebut, dua ayat diungkapkan dengan perumpamaan yang jelas (ayat 59 dan ayat 117) dan satu ayat lagi diungkapkan dengan perumpamaan yang tersembunyi (ayat 103). Ketiga ayat tersebut mengungkapkan fakta tentang penciptaan Nabi Adam as (diciptakan tanpa ayah dan ibu) yang sebenarnya lebih menakjubkan dari penciptaan Nabi Isa as (diciptakan tanpa ibu). Melalui ketiga ayat tersebut dapat diambil hikmah tentang pentingnya berpegang teguh kepada tali Allah dan ketidakbermanfaatan harta yang dinfakkan untuk memerangi Allah dan RasulNya.

Keyword: Al-Qur'an, Ayat-ayat Perumpamaan, Surat Ali Imran

Ferki Ahmad Marlion \& Tri Yuliana Wijayanti । 


\section{PENDAHULUAN}

Allah swt memberikan anugerah kapada para RasulNya dengan kemukjizatan yang luar biasa. Mukjizat yang diterima oleh para rasul sesuai dengan kondisi kaumnya yang bertujuan untuk mengukuhkan kedudukan mereka dan melemahkan segala tipu daya yang dibuat untuk mencelakakan dirinya. Salah satu mukjizat luar biasa yang Allah turunkan kepada rasulNya ialah pada Nabi Muhammad saw dengan diturunkannya Al-Qur'an.

Al-Qur'an merupakan kitab suci umat Islam yang dipenuhi kemu'jizatan, diantara bentuk kemukjizatan itu terlihat dalam keindahan bahasa dan sastranya, pemberitaan terhadap umat yang terdahulu maupun peristiwa yang akan datang, serta kandungan berbagai hikmah dibalik syariat dan ketentuan yang ditetapkan Allah swt. ${ }^{1}$ Al-Qur'an dengan ketinggian nilainya akan terus menanjak tinggi,

1 Ferki Ahmad Marlion, Metode Pendidikan Dipelajari dari Metode Bijak dalam Al-Quran, Tesis tidak diterbitkan, (Jakarta: UIN Syarif Hidayatullah, 2017), 1. jauh diluar batas kemampuan manusia. Ketinggian Al-Qur'an tidak akan mampu disamai oleh karya manusia meskipun hanya membuat satu ayat saja. Ketinggian nilai itu diataranya tercermin didalam katakatanya, kalimatnya yang tersusun rapi, kandungan hikmah yang terkadung didalamnya, serta iktibar untuk dipelajari. ${ }^{2}$

Al-Qur'anul Karim diturunkan sebagai pedoman berisi terkait berbagai pembahasan yang sangat bermanfaat sekaligus dibutuhkan oleh seluruh manusia dalam berbagai kondisi dan waktu. Misalnya, dalam metode pembelajaran serta cara menanamkan sebuah nilai dan hikmah dalam hati seseorang. Dalam hal ini Al-Qur'an menggunakan metode yang indah, simpel dan paling jelas yang salah satunya ialah metode perumpamaan. Metode perumpamaan ini digunakan untuk menyampaikan masalah-masalah yang sangat penting dan krusial,

${ }^{2}$ Ferki Ahmad Marlion dan Ahmad Dardiri, أسلوب الحكيم في القرآن الكريع: دراسة تحليلية , ربلاغية, Jurnal lughawiyah, Vol. 1, No. 2. (2019), 63. 
seperti masalah aqidah, gambaran kondisi orang-orang yang mentauhidkan Allâh Azza wa Jalla, persoalan seputar syirik dan kondisi kaum musyrik, serta berbagai amalan besar lainnya. Tujuan dari metode perumpamaan ini tentu untuk memahamkan dan menanamkan nilai-nilai luhur yang abstrak dengan cara menggambarkannya dengan sesuatu yang kongkrit, sehingga seakan-akan terlihat oleh panca indra. Oleh karena itu, merupakan suatu keharusan bagi seorang hamba untuk memperhatikannya dan berusaha untuk memahami maksud ayat-ayat perumpamaanperumpamaan tersebut.

Dari segi bahasa, sighat al-mastl dan kata-kata yang diambil darinya memiliki arti penggambaran, penjelasan, tampak, hadir, dan mempengaruhi. Al mitsl adalah sesuatu yang dibuat dan dijadikan permisalan yang dengannya makna akan menjadi jelas serta yang membacanya akan terpengaruh dengan perumpamaan itu. Al mits atau perumpamaan adalah rangkaian penyusunan yang memaparkan contoh yang jelas dan terkenal tentang benda-benda yang wujud, atau peristiwa-peristiwa alam, atau sejarah dengan suatu pemaparan yang menarik pandangan untuk menyamakan, atau membandingkan dengan perilaku manusia, atau pemikiran yang murni, atau memberikan nilai, atau meyakinkan pendengar, atau makna apapun dengan tujuan untuk menjelaskan sekaligus membuktikan, dan memberi contoh.

Perumpamaan di dalam AlQur'an juga dapat memperlihatkan dengan gamblang kebenarankebenaran yang tersembunyi, mengangkat tirai-tirai hakikat kebenaran, mengubah orang yang ragu menjadi yakin, orang yang membaca atau mendengarnya seolah olah menyaksikan lansung peristiwa atau permisalan yang disampaikan untuk dapat diambil pelajaran serta hikmah yang terkandung didalamnya. Akan tetapi, ayat-ayat perumpamaan yang terdapat di dalam Al-Qur'an lebih sering 
dipandang biasa bahkan cenderung diremehkan. Padahal ayat-ayat tersebut memiliki nilai yang tinggi dan syarat akan makna, jika dipahami dengan baik. Oleh sebab itu, memaknai ayat-ayat perumpamaan di dalam Al-Qur'an sangatlah penting untuk dijadikan sebuah kajian yang salah satunya ayat-ayat perumpamaan di dalam surat Ali Imran yang sarat akan makna.

\section{MASALAH DAN TUJUAN PENELITIAN}

Memperhatikan latar belakang di atas, maka yang menjadi permasalah dalam penelitian ini adalah bagaimana makna ayat-ayat perumpamaan yang terdapat dalam surat Ali Imran. Memperhatikan permasalahan dalam penelitian ini, maka tujuan yang hendak dicapai dalam penelitian ini adalah untuk menjabarkan makna ayat-ayat perumpamaan yang terkandung dalam surat Ali Imran.

\section{TINJAUAN PUSTAKA}

Penelitian tentang tamtsil sudah beberapa kali dilakukan oleh peneliti- peneliti sebelumnya. Diantara peneliti tersebut adalah pertama Mahbub Nuryadien dengan judul “Penelitian Amtsal: Media Pendidikan Dalam Al-Qur'an" menerangkan bahwa amtsal AlQur'an memiliki peranan yang besar dalam pendidikan dan sejalan dengan ruh pendidikan. ${ }^{3}$ Metode pembelajaran melalui amtsal AlQur'an (penyampaian nasehat dan peringatan) mempermudah pemahaman siswa selain itu penyampaian materi pembelajaran akan lebih menarik jika disampaikan melalui cerita atau ungkapanungkapan yang indah. Letak perbedaan artikel ini dengan artikel peneliti ialah artikel ini menfokuskan pada obyek pendidikan sedangkan peneliti menfokuskan pada tamtsil di surat Ali Imran.

Kedua, H. M. Rusydi Khalid dengan judul "PerumpamaanPerumpamaan Dalam Al-Qur'an (Amsal Al-Qur'an)" memaparkan bahwa amsal Al-Qur'an ialah kalimat

3 Mahbub Nuryadien, Penelitian Amtsal: Media Pendidikan Dalam Al-Qur'an, dalam Jurnal Risalah, Vol. 4, No .2 (2018), 29. 
di dalam Al-Qur'an yang diungkapkan dalam bentuk tamsil, perbandingan, perumpamaan antar sesuatu yang memiliki aspek kemiripan. ${ }^{4}$ Letak perbedaan antara artikel ini dengan artikel peneliti ialah artikel ini menfokuskan pada perumpamaan-perumpamaan yang ada dalam Al-Qur'an sedang artikel peneliti menfokuskan pada tamtsil pada surat Ali Imran.

Ketiga, Muhammad Ali dengan judul "Fungsi Perumpamaan Dalam Al-Qur'an" menuliskan bahwa perumpamaan (tamtsil) merupakan kerangka yang dapat menampilkan makna dalam bentuk yang indah dan mudah untuk dipahami indra manusia, sehingga lebih dapat mendorong jiwa lebih mudah memahami, menerima, dan mengamalkan sesuai dengan makna yang sesungguhnya dimaksud. 5 Letak perbedaan antara artikel ini dengan artikel peneliti ialah artikel

${ }^{4}$ H. M. Rusydi Khalid, PerumpamaanPerumpamaan Dalam Al-Qur'an, dalam Jurnal Adabiyah, Vol. 11, No. 1, (2011), 42.

${ }^{5}$ Muhammad Ali, Fungsi Perumpamaan Dalam Al-Qur'an, dalam Jurnal Tarbawiyah, Vol. 10, No. 2., (2013), 29. ini menfokuskan pada fungsi perumpamaan (amtsal) dalam AlQur'an sedang artikel peneliti menfokuskan pada tamtsil pada surat Ali Imran.

Keempat, Ahmad Haromaini dengan judul "Studi Perumpamaan Al-Qur'an" menuliskan bahwa amtsal Al-Qur'an merupakan salah satu metodologi yang efektif dalam penyampaian pesan di tengah masyarakat yang mengalami kesulitan memahami setiap pesan yang diungkapkan dalam Al-Qur'an. ${ }^{6}$ Letak perbedaan antara artikel ini dengan artikel peneliti ialah artikel ini menfokuskan pada perumpamaan dalam Al-Qur'an secara luas sedang artikel peneliti hanya menfokuskan pada tamtsil pada surat Ali Imran.

\section{METODOLOGI}

Obyek penelitian yakni yang dijadikan fokus perhatian dalam penelitian. ${ }^{7}$ Adapun yang menjadi fokus pada penelitian ini ialah makna

6 Ahmad Haromaini, Studi Perumpamaan Al-Qur'an, dalam Jurnal; Islamika, Vo. 13, No. 1, (2019), 24.

7 Suharsimi Arikunto, Prosedur Penelitian Suatu Pendekatan Praktek, (Jakarta: Reneka Cipta, 1988), 64. 
yang terkandung di dalam ayat-ayat perumpamaan pada Surat Ali Imran.

Metode yang digunakan untuk pengumpulan data di dalam penelitian kualitatif ini yakni metode telaah pustaka yang bertujuan untuk mendapatkan gambaran dan penjelasan yang mendalam terkait makna yang terkandung di dalam ayat-ayat perumpamaan pada Surat Ali Imran.

Penelitian ini menggunakan analisis data deduktif yang selanjutnya disampaikan secara deskriptif untuk memaparkan fokus penelitian (makna ayat-ayat perumpamaan dalam Surat Ali Imran) sistematis dan sejelas mungkin. ${ }^{8}$ Penelitian yang termasuk dalam penelitian kualitatif ini, setelah selesai melakukan analisis dari telaah seluruh data primer (buku tafsir dan buku ulumul Qur'an) maupun sekunder (buku pendukng, e-jurnal, dan hasil penelitian baik yang berbentuk skripsi maupun tesis) kemudian hasilnya dideskripsikan

8 Bakker dan Zubair, Metodologi Penelitian Filsafat, (Yogyakarta: Kanisius, 1990), 76. melalui metode penyajian informal, yaitu perumusan dengan kata-kata biasa $^{9}$

\section{PEMBAHASAN}

1. Perumpamaan di Dalam AlQur'an

a. Pengertian Tamtsil/Amtsal Amtsal ialah bentuk jamak dari kata matsala. ${ }^{10}$ Kata matsal, mitsl, dan matsil serupa dengan syabah, syibh serta syabih dalam sudut makna lafal. ${ }^{11}$ Amtsal secara etimologi dapat bermakna perumpamaan, membandingkan sesuatu dengan sesuatu atau permisalan. Dari kata al-matsal inilah muncul pengertian tamtsil atau perumpamaan ${ }^{12}$.

Amtsal dalam pandangan Ibnu Qayyim dipahami sebagai menyerupakan sesuatu dengan

${ }^{9}$ Sudaryanto, Metode dan Aneka Teknik Analisis Bahasa, (Yogyakarta: Duta Wacana University Press, 1993), 44.

${ }^{10}$ Ahmad Warson Munawwir, Kamus Arab-Indonesia, (Surabaya: Pustaka Progresif, 1997), 1309.

11 Syaikh Manna' Al-Qaththan, Pengantar Studi Ilmu Al-Qur'an, (Jakarta: Pustaka Al Kautsar, 2006), 353.

12 Ahmad Darbi, Ulum Al Quran, (Pekan Baru: Suska Press, 2011), 50. 
sesuatu atau mendekatkan

sesuatu yang abstrak (ma'qul)

dengan yang konkrit (makhshus)

atau mendekatkan salah satu

dari dua makhshus dengan yang

lain dan menganggap salah

satunya itu sebagai yang lain. ${ }^{13}$

Sedangkan Manna' al Qaththan

mendefinisikan amtsal sebagai

menonjolkan makna dalam

bentuk yang menarik dan padat

sehingga

mudah

mempengaruhi jiwa yang

ditampilkan dalam bentuk

tasybih maupun kalimat bebas

lainnya. ${ }^{14}$ Berdasarkan definisi-

definisi tersebut, maka dapat

dimaknai bahwa amtsal ialah

menyusun perumpamaan

tentang suatu keadaan ke dalam

keadaan yang lain baik dengan

isti'arah, tasybih, atau dengan

cara yang lain.

b. Bentuk-Bentuk Amtsal

13 Syahidin, Menelusuri Metode Pendidikan Dalam Al Qur'an, (Bandung: ALFABETA, 2009), 79.

${ }^{14}$ Mahbub Nuryadien, Amtsal: Media Pendidikan Dalam Al-Quran, dalam Jurnal Risalah, Vol. 4, No. 2, (2018), 18.
Bentuk amtsal terdiri dari empat bentuk, yakni: ${ }^{15}$

1) Mengubah hal yang abstrak (ghair al-Makh u) menjadi makh $u$ (konkrit).

2) Mengubah hal yang sulit dijangkau oleh akal menjadi mudah untuk dipahami.

3) Mengubah hal yang luar biasa (tidak dijumpai pada adat kebiasaan) menjadi hal yang biasa dalam keseharian.

4) Mengubah dari yang tidak dapat disifati (dijelaskan) menjadi dapat disifati dan dijelaskan.

Dari empat bentuk amtsal di atas terlihat bahwasanya sebuah ungkapan yang digubah menjadi bahasa tamtsil, maka ungkapkan itu akan mudah untuk dipahami, maksud dan tujuannya 
menjadi jelas, bahasanya

menjadi lebih indah dan

menarik, serta luas dan

dalam pengertiannya.

Ibrahim

an-Nizami

berpandangan bahwa

tamtsil memiliki empat

keistimewaan, yakni

pengertiannya tepat,

mengena, tasybihnya indah

dan sindirannya tajam

c. Macam-macam Amtsal

Manna'

al-Qaththan

membagi tamtsil/amtsal menjadi tiga, yakni: 16

1) Amtsal al Musarraha

Ungkapan lafal matsal disampaikan secara jelas dan tegas atau ungkapan yang menunjukkan tasybih (tasybih menggunakan kata al Amtsal. Matsal yang menggunakan kata al-matsal disebut dengan matsal ahir (terang), oleh karena itu ayat-ayat yang terkandung didalamnya al-matsal

${ }^{16}$ Manna' al-Qaththan, Pembahasan Ilmu al-Qur'an II, (Jakarta: PT Rineka Cipta, 1995), 107. disebut sebagai matsal musharraha atau ahir (terang).

2) Al Amtsal al Kamina

Ungkapan Amtsal yang tidak disebutkan dengan jelas lafal tamtsil nya, namun menunjukkan keindahan maknanya, menarik, padat, redaksinya singkat, dan mempunyai pengaruh tersendiri bila dipindahkan kepada makna yang serupa dengannya, misalnya dalam surat al-Baqarah ayat $68, \mathrm{Al}$ Furqan ayat 67, dan Al Isra ayat 110 .

3) Al Amtsal al Mursala

Kalimat tidak menggunakan lafal tasybih secara jelas, namun kalimat tersebut termasuk matsal, misalnya dalam surat al Mudatsir ayat 38.

Terdapat perbedaan pendapat dari kalangan ulama terkait hukum menggunakan ayat-ayat yang terkandung 
didalamnya amtsal mursala

sebagai matsal. Sebagian

ulama berpandangan bahwa

pengunaan amtsal mursala

sebagai matsal telah

melanggar adab atau etika

terhadap Al-Qur'an, karena

tujuan

Al-Qur'an

diturunkan bukan untuk

dijadikan matsal namun

untuk menjadi bahan tafakur

dan diamalkan. Sebagian

ulama lain berpandangan

bahwa tidak terdapat

halangan jika seseorang

mempergunakan Al-Qur'an

sebagai matsal selama

mempergunakannya secara

serius dan tidak dijadikan

bahan permainan.

d. Manfaat Amtsal

Beberapa manfaat Amtsal antara lain:

1) Menampilkan sesuatu yang ma'qul (rasional) dan dapat ditangkap oleh indra manusia, sehingga akal mudah memahami sesuatu yang abstrak dan sulit untuk dipahami.

2) Mengungkapkan

hakikat sesuatu yang tidak terlihat menjadi seolah-olah terlihat.

3) Menghimpun makna yang menarik dan indah dalam satu ungkapan yang padat.

4) Mendorong manusia yang disebut dalam matsal untuk mengaplikasikan kandungan matsal, misal dalam surat Al Baqarah ayat 261 .

5) Menjauhkan diri jika isi matsal memuat hal yang dibenci jiwa, misalnya dalam surat Al Hujurat ayat 12 .

6) Memuji manusia yang diberi matsal.

7) Menggambarkan karaktek atau atau watak yang dipandang buruk oleh orang banyak. 
8) Amtsal lebih mudah mempengaruhi jiwa manusia, lebih efektif untuk menyampaikan nasehat, lebih kuat untuk memberikan peringatan, dan memberikan kepuasan hati.

2. Ayat-Ayat Perumpamaan Dalam Surat Ali Imran

Surat Āli Imrān (آل (عمران merupakan suratke-3 di dalam Al-Qur'an. Surat ini terletak setelah surat Al-Baqarah dan sebelum surat An-Nisa'. Surat yang termasuk ke dalam surat Madaniyah ini terdiri dari 200 ayat. Dari permulaan surat hingga ayat delapan puluh tiga dalam surat ini merupakan ayat yang turun berkenaan dengan utusan Najran. Surat Al-Baqarah dan Āli 'Imrān ini dinamakan $A z$ Zahrawan (dua yang cemerlang), karena kedua surat ini mengungkapkan hal-hal yang menurut Al-Qur'an disembunyikan oleh para Ahli Kitab (Yahudi dan Nasrani), seperti kejadian kelahiran
Nabi Isa as yang lahir tanpa ayah dan kedatangan Nabi Muhammad saw sebagai penutup para Nabi dan Rasul.

Surat ini dinamai Ali Imran, karena di dalamnya diceritakan kisah keluarga Imran, yaitu: Nabi Isa as, Nabi Yahya as, serta kisah Maryam. Sedangkan Imran merupakan ayah dari Maryam ibunya Nabi Isa as. Surat ini sebenarnya memiliki banyak nama, antara lain surat al-amanu (keamanan), al-kanz dan thibah, tetapi yang populer adalah Ali Imran. Tujuan utama dari surat Ali Imran adalah pembuktian tentang tauhid, aqidah, keesaan dan kekuasaan Allah swt, serta penegasan bahwa dunia, kekuasaan, harta, dan anak-anak yang terlepas dari nilai-nilai Ilahiyah-kesemuanya--tidak akan memberi bermanfaat di akhirat.

Surat Ali Imran mengandung mukjizat yang besar dari segi bahasanya, termasuk ayat-ayat perumpamaan yang bisa diambil hikmah dan pelajaran. Didalam surat Ali Imran terdapat tiga ayat perumpamaan, yaitu: 
a. QS. Ali Imran Ayat 59

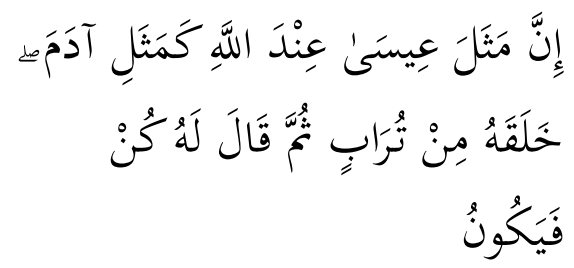

Artinya: Sesungguhnya misal (penciptaan) Isa di sisi AllAh, adalah seperti (penciptaan) Adam. Allah menciptakan Adam dari tanah, kemudian Allah berfirman kepadanya: "Jadilah" (seorang manusia), maka jadilah dia.

b. QS. Ali Imran Ayat 103

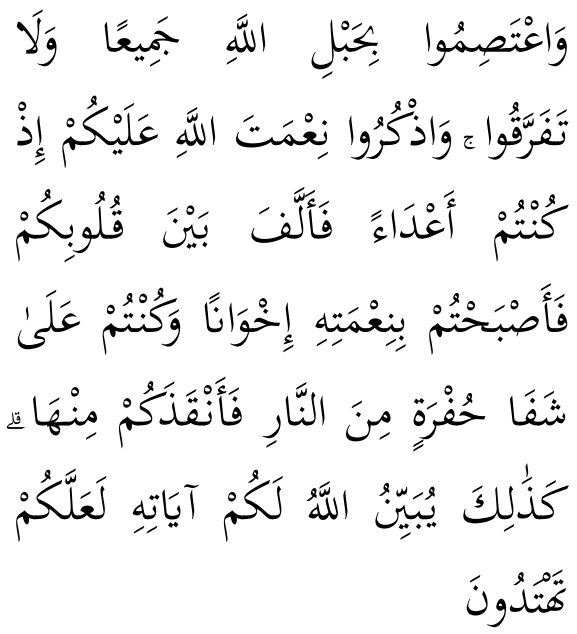

Artinya: Dan berpeganglah kamu semuanya kepada tali (agama) Allah, dan janganlah kamu bercerai berai, dan ingatlah akan nikmat Allah kepadamu ketika kamu dahulu (masa Jahiliyah) bermusuhmusuhan, maka Allah mempersatukan hatimu, lalu menjadilah kamu karena nikmat Allah, orang-orang yang bersaudara; dan kamu telah berada di tepi jurang neraka, lalu Allah menyelamatkan kamu dari padanya. Demikianlah Allah menerangkan ayat-ayatNya kepadamu, agar kamu mendapat petunjuk.

c. QS. Ali Imran Ayat 117

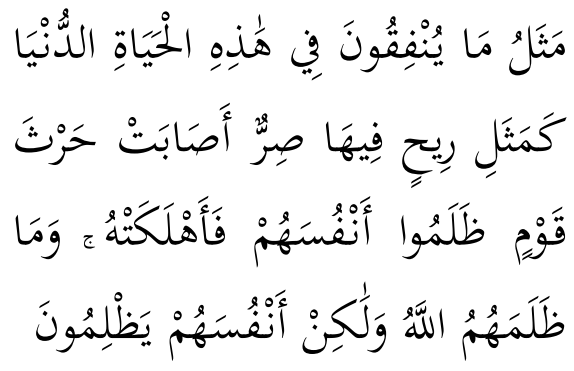

Artinya: Perumpamaan harta yang mereka nafkahkan di dalam kehidupan dunia ini, adalah seperti perumpamaan angin yang mengandung hawa yang sangat dingin, yang menimpa tanaman kaum yang menganiaya diri sendiri, lalu angin itu merusaknya. Allah tidak menganiaya mereka, akan tetapi merekalah yang menganiaya diri mereka sendiri.

3. Makna

Ayat-Ayat

Perumpamaan Dalam Surat Ali Imran

Terdapat tiga buah ayat perumpamaan dalam Surat Ali Imran yang terkandung makna yang mendalam dan tinggi bahasanya.

a. QS. Ali Imran ayat 59

Asbabun nuzul dari ayat ini diceritakan oleh 
Muhammad bin Sawah Al fawadisi bahwa Abdy bin Humaid berkata, kami mendapatkan riwayat dari Rauh bin Abadah, dari Auf al-Arabi dari Azraq bin Qais berkata, "seorang uskub Najran dan pengawalnya menemui Rasulullah dan Rasulullah menawarkan kepada mereka untuk masuk Islam. Mereka menjawab "kami sudah Muslim sebelum Anda". Kemudian Rasulullah bersabda "kalian berdusta, ada tiga hal yang menghalangi kalian dari Islam: yakni ucapan kalian Allah mengambil anak, kalian bersujud kepada salib, dan kalian memakan daging babi". Uskub Najran itu bertanya, "siapa ayahnya isa ?". Kemudian Rasulullah tidak menjawab pertanyaan mereka itu, lalu Allah menurunkan ayat, “Sesungguhnya misal (penciptaan) Isa di sisi Allah, adalah seperti (penciptaan) Adam. Allah menciptakan Adam dari tanah, kemudian Allah berfirman kepadanya: "Jadilah" (seorang manusia), maka jadilah dia" ${ }^{17}$

Kata-kata matsala (مَثَلَ) merupakan petunjuk bahwa ayat ini merupakan ayat perumpamaan. Letak perumpamaan pada ayat ini adalah bahwa penciptaan Nabi Adam dan Nabi Isa tanpa seorang ayah. Bahkan penciptaan nabi Adam tanpa adanya seorang ibu. Karena itulah pentingnya menyebutkan aspek kesamaan dengan firman Allah "Allah menciptakan Adam dari tanah...." maksudnya, Allah menciptakan Nabi Adam tanpa seorang ayah dan ibu. 
Tapi hanya dengan menggunakan kalimat "jadilah". Hal ini menyeru bahwa penciptaan Nabi Isa yang tanpa seorang ayah sebenarnya tidak lebih menakjubkan dari penciptaan Nabi Adam. Hal in membantah pendapat (logika) Uskub Najran tersebut yang merasa aneh dan takjub dengan penciptaan nabi Isa. Perumpamaan dalam ayat ini menunjukkan bahwa pertanyaan ahlul kitab kepada Nabi Muhammad dapat dibantah dengan membandingkan hal yang serupa bahkan lebih menakjubkan dengan yang mereka ketahui tentang kelahiran Nabi Isa.

Perumpamaan (al-mitsl) dalam ayat ini termasuk ke dalam kategori perumpamaanperumpamaan yang tegas karena langsung menggunakan kata sebagai wujud perumpamaanya. Dengan faedah menonjolkan rasionalitas dengan memberikan perbandingan lain yang sepadan dan memiliki persamaan, sehingga penanya menjadi takjub dan memahami tentang kelahiran Nabi Isa sama dengan diciptakannya Nabi Adam. Faedah yang lain dalam perumpamaan ini adalah mengungkapkan fakta-fakta yang lebih menakjubkan dan tersembunyi tentang proses diciptakannya Nabi Adam yang dilahirkan tanpa seorang ayah dan ibu, sehingga bisa menarik jiwa dan pikiran manusia tentang hak preogratif Allah menciptakan dan berbuat diluar dari hal yang biasa dilihat manusia.

Setelah Rasulullah jelaskan penciptaan Nabi Isa 
dan kedatangannya dengan mengutip ayat-ayat tersebut, dan juga keadaan kaumnya ada yang kafir, beriman dan ragu-ragu, Rasuulah berhasil mengungkap kerancuan yang dengan sengaja disiarkan oleh orang-orang yang terkena fitnah tetang penciptaan Nabi Isa diluar proses almiah serta memberi keterangan yang gamblang kepada orangorang yang membantah tanpa didasari dengan pengetahuan.

Perumpamaan ini juga tidak membantah kelahiran Nabi Isa tanpa sebab yang alami seperti hal nya penciptaan Nabi Adam dengan kalimat "jadilah".

b. QS. Ali Imran ayat 103

$$
\text { Perumpamaan dalam }
$$
ayat ini termasuk kepada perumpamaan yang tersembunyi, karena tidak disebutkan dengan jelas dan tegas lafadz al-matsl/matsala.

Tetapi hal ini menunjukkan beberapa makna perumpamaan yang ringkas dan jelas seperti terdapat dalam kalimat بحَبْبل اللَّ dan dan lafadz شَفَا حُفْرَة

Adapun makna اللَّبْل memiliki enam macam penafsiran, yakni:

1) بح بحَبْل اللَّهُ memiliki makna kitab Allah yang diturunkan kepada Nabi Muhammad saw, yaitu Al-Qur'an. Penafsiran ini menurut pendapat Ibnu Qatadah, Syaqiq, Ad-Dhahak dan Abdurrahma As-Suda'.

2) بِكَبْل النَّهِ memiliki makna persatuan. Ini merupakan pendapat Asy-Syu'bi.

3) بحكَبْل النَِّّ memiliki makna agama Allah. Ini merupakan pendapat 
Ibnu Abbas, Ibnu Zaid, Muqatil, dan Ibnu Qutaibah.

4) بحِبَبْل اللَّهِ memiliki makna janji Allah. Ini adalah pendapat Mujahid, Aha' dan Abu Ubayd.

5) بحَبْْل اللَّهِ memiliki makna keikhlasan. Ini merupakan pendapat dari Abu Aiyah.

6) بحَحَبْل اللَّهِ memiliki mana perintah Allah. Ini merupakan pendapat Muqatil bi Hayyan.

Dengan banyaknya pendapat dan penafsiran tentang lafadz tersebut, menandakan bahwa "tali Allah" merupakan perumpamaan yang menggambarkan sesuatu yang kuat, dijadikan tempat bergantung, atau penghubung sesuatu yang terputus, sehingga umat Muslim diperintahkan untuk berpegang teguh kepada "tali Allah" tersebut sehingga "tali Allah" itu bisa mencegah perpecahan.

$$
\text { Adapun lafadz شَفَا حُفْرَةِ }
$$

merupakan perumpamaan orang yang berada di tepi sebuah jurang, kemudian Allah menyelamatkan mereka dengan tali Allah tersebut. Hal ini bisa digambarkan dengan dua buah suku yang selalu berperang selama seratus dua puluh tahun sebelum Islam datang. Suku tersebut bernama Aus dan Khazraj. Mereka saling berperang, padahal mereka bersaudara. Kemudian Allah padamkan peperangan dan permusuhan diantara mereka dan menyelamatkan mereka dengan tali Allah berupa datangnya Islam.

Suku Aus dan Khazraj berada ditepi jurang neraka, karena permusuhan dan peperangan yang selalu 
mereka lakukan selama

seratus dua puluh tahun, kemudian Allah selamatkan mereka dengan datangnya Islam yang dibawa oleh nabi Muhammad saw.

Perumpamaan pada ayat ini memberikan makna yang indah dengan ungkapan yang ringkas, serta memberikan petunjukpetunjuk yang jelas untuk dijadikan pedoman dalam aktifitas sosial dan masyarakat. Sehingga Muslim berpegang teguh kepada tali Allah agar tidak tersesat dan terlepas dari petunjukNya, Muslim pun disyariatkan untuk bersyukur kepada Allah dengan banyaknya nikmat yang telah didapatkan.

c. QS. Ali Imran Ayat 117

Ayat ini merupakan ayat perumpamaan yang nyata, tegas dan jelas, karena adanya lafadz Ayat ini menggambarkan perumpamaan orang yang menginfakkan hartanya, tetapi tidak mengakui keesaan Allah dan mengingkari akan kerasulan Nabi Muhammad saw. Harta mereka seperti angin yang mengandung hawa yang sangat dingin yang menerpa tanaman suatu kaum yang sangat mengharap hasil dari tanaman mereka, tetapi tanaman tersebut tidak memberikan manfaat sedikitpun kepada mereka. Rasyid Ridha mengatakan bahwa angin berhawa dingin yang menghancurkan صِيحِ فِيهَا صِر itu adalah perumpamaan untuk harta yang mereka (orang kafir) infakkan demi kepentingan mereka sendiri seperti mempertahankan kedudukan, dianggap dermawan dan menaikkan popularitas mereka. Akan tetapi, hal ini justru 
menghalangi mereka dari jalan Allah.

Para ulama tafsir berpendapat bahwa harta yang mereka infakkan itu adalah harta yang mereka berikan untuk memusuhi Nabi Muhammad saw dengan menghalangi dakwah Nabi dan memberikan mudharat terhadap keselamatan Nabi. Orang-orang tersebut akhirnya mengalami kerugian, karena berkembangnya Islam dan semakin banyaknya pemeluk agama damai tersebut.

Perumpamaan ini menunjukkan kepada kita apa yang dilakukan oleh Allah swt terhadap orang kafir sama dengan apa yang diberikan Allah swt terhadap orang yang dimaksud di dalam ayat tersebut. Allah membatalkan pahala-pahala mereka, karena kezhaliman dan kesalahan yang mereka lakukan. Mereka seharusnya mengakui keesaan Allah, mengikuti perintahNya, membenarkan kerasulan Nabi Muhammad saw, serta tidak menghalangi perkembangan dakwah Islam.

Perumpamaan ini mengungkapkan fakta tentang harta yang diinfakkan bukan karena Allah ternyata akan menjadi sia-sia dan tidak memberikan manfaat sedikitpun seperti tanaman yang dirusak oleh angin yang sangat dingin. Perumpamaan seperti ini akan menjadikan akal lebih mudah membayangkan dan menerima pesan-pesan tersirat yang ada di dalam ayat tersebut. 


\section{SIMPULAN}

Kesimpulan yang dapat ditarik dalam penelitian ini ialah ayat-ayat perumpamaan yang terkandung dalam surat Ali Imran terdiri dari tiga buah ayat, yakni ayat 59, 117, dan 103. Dari ketiga ayat tersebut, dua ayat diungkapkan dengan perumpamaan yang jelas (ayat 59 dan ayat 117) dan satu ayat lagi diungkapkan dengan perumpamaan yang tersembunyi (ayat 103). Ketiga ayat tersebut mengungkapkan fakta tentang penciptaan Nabi Adam as (diciptakan tanpa ayah dan ibu) yang sebenarnya lebih menakjubkan dari penciptaan Nabi Isa as (diciptakan tanpa ibu). Melalui ketiga ayat tersebut dapat diambil hikmah tentang pentingnya berpegang teguh kepada tali Allah dan ketidakbermanfaatan harta yang dinfakkan untuk memerangi Allah dan RasulNya.

\section{Metode tamstsil/amtsal}

(perumpamaan) dalam Al-Qur'an merupakan salah satu metodologi yang efektif dalam penyampaian pesan Al-Qur'an di tengah-tengah masyarakat yang mana masyarakat selama ini seringkali mengalami kesulitan dalam memahami setiap pesan yang terdapat dalam AlQur'an. Oleh karena itu, peneliti berharap agar peneliti-peneliti selanjutnya dapat melanjutkan penelitian terkait ayat-ayat perumpamaan dalam Al-Qur'an secara detail dan sehingga lebih memperkaya khazanah keilmuan tafsir dan dapat menambah pemahaman masyarakat luas. 


\section{DAFTAR PUSTAKA}

Al-Qaththan, Syaikh Manna', Pengantar Studi Ilmu AlQur'an. Jakarta: Pustaka Al Kautsar, 2006.

Al Suyuthi, Jalal al-Dil, Al-Itqan fi 'Ulum al-Qur'an. cet. Ke-1 juz. II. Surabaya: PT Irama Minasari, t.t.

Ali, Muhammad, Fungsi Perumpamaan Dalam AlQur'an. Jurnal Tarbawiyah. Vol. 10. No. 2, 2013.

Arikunto, Suharsimi, Prosedur Penelitian Suatu Pendekatan Praktek. Jakarta: Reneka Cipta, 1998.

Asy-Syawadifi, Muhammad bin Shalah, At-Tibyan fi Amtsalil Qur'an. Darul Kutub: Lebanon, 2020.

Bakker, Anton dan Zubair, Metodologi Penelitian Filsafat. Yogyakarta: Kanisius, 1990.

Darbi, Ahmad, Ulum Al-Qur'an. Pekan Baru: Suska Press, 2011.

Hamis, Shalahuddin, Studi Ulumul Qur'an. Jakarta: Intimedia Ciptanusantara, 2002.

Haromaini, Ahmad, Studi Perumpamaan Al-Qur'an. Jurnal; Islamika. Vo. 13. No. 1, 2019.
Khalid, H. M. Rusydi, PerumpamaanPerumpamaan Dalam AlQur'an. Jurnal Adabiyah. Vol. 11. No. 1, 2011.

Marlion, Ferki Ahmad, Metode Pendidikan Dipelajari dari Metode Bijak Dalam Al-Qur'an. Tesis. Jakarta. UIN Syarif Hidayatullah, 2017.

Marlion, Ferki Ahmad dan Ahmad Dardiri, أسلوب الحكيم في القرآن الكريم: دراسة تحليلية بلاغية التية Jurnal lughawiyah. Vol. 1. No. 2, 2019.

Munawwir, Ahmad Warson, Kamus Arab-Indonesia. Surabaya: Pustaka Progresif, 1997.

Nuryadien, Mahbub, Amtsal: Media Pendidikan Dalam Al-Qur'an. Jurnal Risalah. Vol. 4. No. 2, 2018.

Panggalih, Ridwan Wening, Efektivitas Metode "Amtsal" Dalam Pembelajaran Ajaran Aqidah Akhlak di MTS Al Fatah Maos Kelas VIII. Skripsi. Purwokerto. Fakultas Tarbiyah dan Ilmu Keguruan IAIN Purwokerto, 2017.

Sudaryanto, Metode dan Aneka Teknik Analisis Bahasa. Yogyakarta: Duta Wacana University Press, 1993.

Syahidin, Menelusuri Metode Pendidikan Dalam Al-Qur'an. Bandung: ALFABETA, 2009. 